\title{
Clinical Record
}

sections, to Mr. Maher, the chief of the Photography Department, for his collaboration, and to my colleagues of E.N.T. Department who helped me in many ways to achieve this. study.

\section{REFERENCES}

BAILEy (1948a) "Intracranial tumors," 2nd edit. Springfield, Ill.

(1948b) Ibid., p. I80.

(I948c) Ibid., p. I74.

(I948d) Ibid., p. I87.

Cushing, H., and Eisenhardt, L. (I938) "Meningiomas," p. 42I. Springfield, Ill.

New, G. B., and Devine, K. D. (I947) Arch. Otolaryng., Chicago, 46, I63.

\section{LETTER 'TO THE EDITOR}

To the Editor, The Journal of Laryngology and Otology,

DEAR SIR,

Our attention has been drawn to the manufacture by us of per oral endoscopes designed by Mr. Negus, M.S., F.R.C.S., and carrying his name. It appears that they do not exactly conform with the specification approved by Mr. Negus.

We, therefore, tender to Mr. Negus our sincere regret and an apology, and undertake that in future any per oral endoscopes sold by us and bearing his name shall conform with his specification.

We also desire to intimate our willingness to replace or alter on request any instrument sold under the above misapprehension.

Yours faithfully,

Down Bros. and Mayer \& Phelps, Ltd. 